\title{
Karst water resources and their complex utilization in the Bükk Mountains, northeast Hungary: an assessment from a regional hydrogeological perspective
}

\author{
Rita Miklós ${ }^{1}$ - László Lénárt ${ }^{1}$ Enikő Darabos ${ }^{1} \cdot$ Attila Kovács $^{2}$ • Ágnes Pelczéder ${ }^{3}$. Norbert Péter Szabó ${ }^{2}$. \\ Péter Szücs ${ }^{1,2}$
}

Received: 3 July 2019 / Accepted: 20 April 2020 / Published online: 11 May 2020

(C) The Author(s) 2020

\begin{abstract}
The cold and thermal karst water resources of the Bükk Mountains play a significant role in the hydrogeological setting of northeastern Hungary. Although there is much geological and hydrogeological information available, the regional hydrogeology of the Bükk Mountains had not been described in a standalone study involving all this information. The drinking water supply of the city of Miskolc and some other neighboring cities is based on the cold karst water resources of the Bükk Mountains. The thermal water resources have been getting more important, in terms of balneology and geothermal energy production, in this region over the last decade. An evaluation of the measurements of a 27 -year-old groundwater quantity and quality monitoring system was performed. As a result, several types of new field hydrogeology, meteorology and spring discharge measurements were added to the monitoring scheme to provide information for studying the tendencies connected to extreme weather conditions. This will help to achieve sustainable utilization of the karst water resources. The main conclusions drawn in this study underline the importance of the strict measures associated with the water management of the Bükk Mountains because of the limited natural recharge and the continuously increasing demands on the cold and thermal water resources. A success story is found in Miskolc, which demonstrates the sustainable utilization of the deep thermal karst water; Miskolc hosts the largest geothermal heating plant in Central Europe with $60 \mathrm{MW}_{\mathrm{t}}$ capacity.
\end{abstract}

Keywords Karst · Groundwater management · Groundwater monitoring · Water supply $\cdot$ Hungary

\section{Introduction}

Bükk Mountains are located in northeast Hungary in the close surroundings of Miskolc. With around 170,000 inhabitants, Miskolc is the most densely populated city in this region and the third largest city in Hungary. This relatively high-elevation karst area, with highest peaks up to $900 \mathrm{~m}$ elevation, is a popular destination for tourists. The size of the uncovered (cold water) karst of the Bükk is around $207 \mathrm{~km}^{2}$, and the size

Rita Miklós

miklos_rita@yahoo.com

1 Institute of Environmental Management, University of Miskolc, Miskolc-Egyetemváros H-3515, Hungary

2 MTA-ME, Geoengineering Research Group, Miskolc-Egyetemváros H-3515, Hungary

3 PANNERGY PLC, Budafoki út 56., Budapest H-1117, Hungary of the water catchment area is about $230 \mathrm{~km}^{2}$ (GDWM 2015). The areal extent of the thermal karst water system of the Bükk is estimated to be $1,000 \mathrm{~km}^{2}$ and its hydrogeological boundaries cannot be delineated exactly because of the lack of detailed geophysical measurements. According to the groundwater-level correlation investigations, there is a close hydraulic relationship between the cold and thermal karst water bodies in the Bükk Mountains (Lénárt et al. 2014). The cold karst-water area of the Bükk Mountains is surrounded by a significantly extended thermal karst-water area (yielding water with temperatures exceeding $30^{\circ} \mathrm{C}$ ) in the east, west and south. About 20-25 karst springs and thermal wells can be found at the rim of the mountains and the surrounding area, yielding tepid $\left(10-25^{\circ} \mathrm{C}\right)$ or warm $\left(25-37^{\circ} \mathrm{C}\right)$ water in springs, or even warmer $\left(25-37^{\circ} \mathrm{C}\right)$ or hot $\left(>37^{\circ} \mathrm{C}\right)$ thermal water in wells. Thermal karst aquifers around the mountains are covered with thick sedimentary layers of Neogene age. Miskolc hosts the famous Cave Bath, which is fed by thermal water that comes from the deep section of the karstic Bükk 
Mountains. On the other hand, this huge karst reservoir is the main water resource for the city water supply in Miskolc (Szücs and Horne 2009).

The most important quantitative monitoring system in the region is the so-called Bükk Karst Water Level Monitoring System, which is operated by the Department of Hydrogeology and Engineering Geology at the University of Miskolc. The first monitoring system measuring karst water levels was installed in 1992, initiated by the water companies operating in the region. The goal of this endeavor was to understand the quantitative parameters of the karst water and to help with the planning of water supply in Miskolc and in the region of the Bükk Mountains. The main motivation for this enterprise was the extreme drought and lack of rainfall, because these had caused problems for the water supply in the previous decades (between 1945 and 1992). This monitoring system has been greatly improved upon during the last few years, to provide more detailed and highly accurate quantitative (e.g. water level, pressure) and qualitative (e.g. pH, electrical conductivity) information about the karst water resources of the Bükk Mountains. Advanced statistical methods such as the popular value-based and nonparametric regression approaches, have been applied to interpret the data of the complex monitoring system (Szücs et al. 2006). Global optimization tools and robust statistical techniques have been applied for treating the measurement data in an appropriate manner and for extracting more information in order to build an extended groundwater-flow model of the research area. The main objective of this report is to demonstrate how the general knowledge and understanding of the hydrogeology and the complex flow systems of the Bükk Mountains have been improved during the last decades. As a result of integrating all the collected information and performing a more robust interpretation, an improved hydrogeological description of the studied area on the regional scale is proposed. This study gives a more comprehensive view of the karst water resources of the Bükk Mountains than ever before and provides more reliable information for the hydrogeologists and water companies. The obtained results are invaluable to guarantee the sustainable and multipurpose karst water management in the investigated region.

\section{Materials and methods}

\section{Geology and hydrogeology of the Bükk Mountains}

Bükk Mountains are the second highest mountains of Hungary, with a maximum height of $958.4 \mathrm{~m}$ (Istállóskő Peak). The most uniform small region is the Bükk Plateau which is divided into two parts by the Garadna Valley. Kis-Fennsík (so called "Small Plateau") is situated to the north of the Garadna Valley. The southern and also higher part is the Nagy-Fennsík (so called "Great Plateau"; Fig. 1). The entire region has been built up over time by well-karstified limestones with special karst features like dolines, sinkholes, large spacious caves, and welldeveloped cave systems (Pelikán 2005).

The Bükk Mountains are basically built up of limestones; however, according to the available surface geological maps, large-scale limestone formations form an allogenic karst that is covered by nonkarstic sediments. The geological structure is related to sequences of the Inner Dinaridic Zone. Due to tectonic movements, Bükk reached its final position in the Late Cenozoic (Filipović et al. 2003). Rock formations appearing in the mountains can be divided in two sequences-first is the Middle Carboniferous-PermianTriassic-Jurassic age formations built up on continental crust, forming the Bükk autochthon. The second sequence was formed on oceanic crust in the Jurassic age which constitutes the so-called Szarvaskő-Darnó-Nappe (Pelikán 2005).

The Bükk Mountains mainly consist of well-karstified platform-facies limestones of Triassic age and less karstified Triassic limestones with marl, clay and chert intercalations. The thickness of the karst-water reservoir can reach several thousand meters. Jurassic slates and Cretaceous volcanites (diabase, gabbro and metabazalt) are present to a large extent on the surface in the western and southwestern parts of the mountains (Pelikán 2005).

A classification of rocks based on hydrogeological features can be found in Fig. 2 and Table 1 (Darabos 2017 and Kovács 2003). These rock categories, including mostly middle and upper-Triassic well-karstified platform limestones (Fehérkő Limestone, Bükkfennsík Limestone, Kisfennsík Limestone, Berva Limestone), are the most important aquifers of the Bükk. Poorly karstified rocks include the Upper-Permian Nagyvisnyó Limestone, the Lower Triassic Gerennavár Limestone, the Middle Triassic Hámor Dolomite, the Upper Triassic Felsőtárkány Limestone and the Jurassic Bükkzsérc Limestone. Aquitards include the Carboniferous Szilvásvárad Formation, the Permian Szentlélek, and the Jurassic Lökvölgy, Vaskapu and Rocskavölgy formations. Also, the aquitards include the Jurassic radiolarites (Bányahegy and Csipkéstető formations). The Triassic-Jurassic metamagmatic rocks including the Szentistvánhegy, Bagolyhegy, Szinva, Létrás, Szarvaskő and Tardos Formations are also aquitards. Some low permeability slates include calcareous intercalations which might yield insignificant karstic waters. These aquitards include the Carboniferous Zobóhegyes and Mályinka, the Lower Triassic Ablakoskővölgy, the Upper Triassic Vesszős, the Jurassic Oldalvölgy and Mónosbél Formations. Nonkarstified, fractured rocks appear mostly in the foreground of the mountains as rhyolite and dacite tuff formations (Table 1).

The Eocene Szépvölgy Limestone is also a well karstified aquifer. Quaternary alluvium might also contain groundwater. The aquitards appearing mostly at the southern rim and foreground of the mountains include clay, marl, rhyolite and dacite tuff and schlier sequences. The coarse-grained Tertiary 


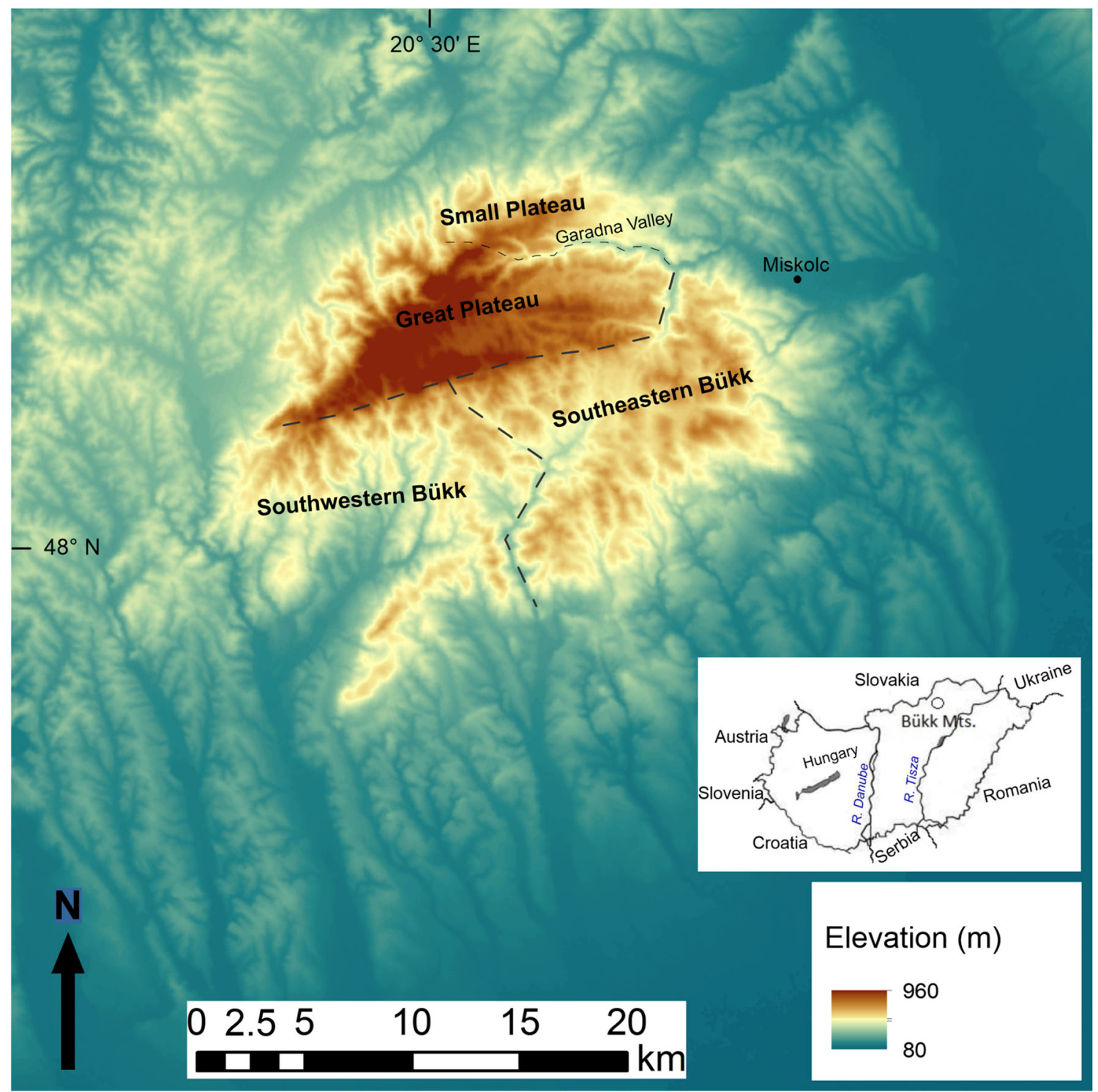

Fig. 1 Topographical map of the Bükk Mountains and their surroundings

sediments and some intercalations within the aquitards might also store groundwater (Pelikán 2005).

The hydrogeological units of the Bükk are determined by its folded geological framework and the alteration of aquifers and aquitards. There are three main hydrogeological units which are separated by significant tectonic elements; however, these units can be hydraulically connected:

1. The Northern unit (Small Plateau), including the northern limb of the Bükk anticline

2. The Middle unit, comprising the southern limb of the Bükk anticline. The Northern unit was pushed upon the Southern unit

3. The Southern unit, including the Middle Triassic-Upper Jurassic sediments. The contact indicates that the Middle unit was pushed upon the Southern unit (Pelikán 2005).
These hydrogeological units can be further subdivided based on geology and also based on tracing experiments, in which the connection of more than a hundred caves, sinkholes and karst springs was investigated using different types of tracers (e.g. fluorescent dyes, salts; L. Sásdi, Mining and Geological Survey of Hungary, unpublished data, 2000).

\section{Hydrological issues}

\section{Recharge and discharge conditions}

The long-term annual precipitation in the Bükk varies between 650 and $800 \mathrm{~mm}$ depending on topographic elevation. Higher values are measured in the uplands area, while lower values are characteristic of the foothills of the Bükk. The surface waters of the Bükk belong to the catchment of the Tisza 
Fig. 2 Hydrogeological category map (Darabos 2017) including the main hydrogeological units $(1,2,3$; adapted from Pelikán 2005) in the Bükk Mountains and their close surroundings

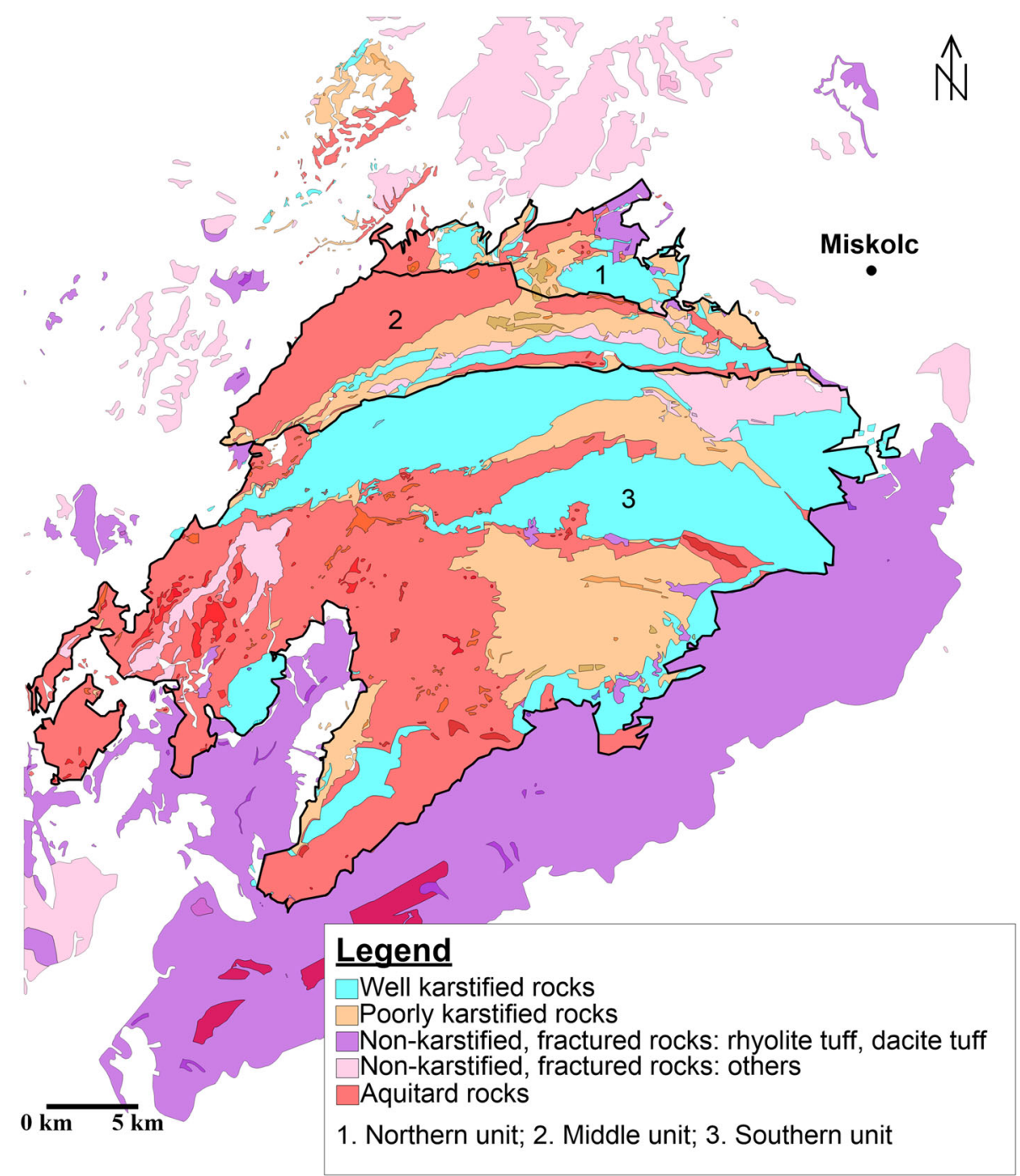

River. In the karstified upland areas, there are no surface waters present, as rainfall infiltrates directly into the karst system through sinkholes and diffuse recharge. Sinking streams reappear in the major karstic springs; most of these have been clarified through tracing experiments (Sásdi 2002).

There is a large number of sinkholes registered across the Bükk. Most of these have formed on the borders of lowpermeability rocks and karstified limestones. Some of these sinkholes involve sinking streams where surface waters of the allogenic catchment disappear underground. Other sinkholes are located in the riverbed of permanent or temporary streams.

A large number of springs are registered in the Bükk area, of which 65 are significant springs with discharges of $0.17-$ $0.67 \mathrm{~m}^{3} / \mathrm{s}$. The original discharge of some of the major springs dropped following the installation of extraction wells in the vicinity of Miskolc and Eger (Izápy and Sárváry 1993). The long-term average discharge of the Bükk springs is $2.23 \mathrm{~m}^{3} / \mathrm{s}$. The total catchment area (including allogenic recharge) is

Table 1 Hydrogeological categories and associated porosity values in the Bükk Mountains (Darabos 2017)

\begin{tabular}{lll}
\hline Hydrogeological category & Rock type & $\begin{array}{l}\text { Porosity } \\
(v / \mathrm{v})\end{array}$ \\
\hline Well karstified rocks & Limestone & 0.0075 \\
Poorly karstified rocks & Dolomite, limestone & 0.0025 \\
Nonkarstified, fractured rocks (tuff) & Rhyolite tuff, dacite tuff & 0.001 \\
Nonkarstified, fractured rocks (others) & Metamagmatic rocks & 0.001 \\
Aquitard rocks & Siltstone, turbidite, sandstone, claystone, radiolarite, shale, schist, siltstone shale & 0.0005 \\
\hline
\end{tabular}


$280 \mathrm{~km}^{2}$, while the long-term average recharge calculated for the Bükk is $32.4 \%$. On the karstic upland area, the annual recharge is assumed to exceed 36\% (Izápy and Maucha 1992). While the springs located in the central unconfined parts of the aquifer discharge cold waters, the springs located along the foothills of the Bükk discharge thermal waters (Eger, Miskolctapolca, Diósgyőr, Sály, Kács, Mónosbél). These thermal springs discharge waters from deep aquifers confined by low-permeability Tertiary sediments. The temperature of the thermal springs varies between 25 and $30^{\circ} \mathrm{C}$. The age of the thermal waters determined through ${ }^{14} \mathrm{C}$ and ${ }^{3} \mathrm{H}$ analyses is 7,300-15,000 years (Deák 1989).

\section{Flow system}

Triassic limestones comprise an important water resource. The whole karstic system is hydraulically interconnected at the regional scale, but also includes several karstic catchments with local groundwater flow systems. Some of the subsystems are interconnected below the karstification horizon, while others are hydraulically separated by low-permeability rocks (Kovács et al. 2015).

Karstic surface features are widespread on the Bükk Plateau. Triassic limestones of the Bükk generally constitute a continuous carbonate reservoir which extends beyond the foot of the mountains and continue at a depth of several thousands of meters below the basin floor. About 20-25 karst springs and thermal wells can be found at the rim of the mountain and the surrounding area, yielding thermal waters. Where horst structures exist below the tertiary cover, thermal waters are discharging. Such structures extend to the south of Eger (Andornaktálya, Egerszalók), where water temperature exceeds $30^{\circ} \mathrm{C}$. In the area of Egerszalók and Demjén, exploited thermal water temperatures vary between 59 and $82{ }^{\circ} \mathrm{C}$.

\section{Water supply issues}

Water shortage may occur in the area during sustained dry periods, when decreased spring discharges are insufficient to cover the water demand. During drought periods, karst water supplies of the city of Miskolc are complemented by imported water from the nearby bank-filtered resources. Settlements located at higher elevations (Bükkszentkereszt, Ómassa, Répáshuta) have no backup water resources, and thus tankwater needs to be distributed at these localities during droughts or in case of havaria (like karst floods). The karst springs of the Bükk also supply groundwater-dependent ecosystems, which require some proportion of spring discharge to be released for ecological reasons. During droughts, the environmental criteria cannot be met, generating water conflict between human needs and ecological demands.
Karst water of the Bükk is generally of excellent quality, but after heavy rainfalls mobilized particles generate high turbidity, and bacterial infection might also happen (such an event occurred in 2006 and 2010, resulting in the hospitalization of hundreds of people). During karstic floods, contaminated water might enter the karst conduit system through sinkholes and can reach the waterworks within a few days. Although there are several communities across the Bükk where the sewage system had not been developed until recently, the nitrate concentration is generally below $20 \mathrm{mg} / \mathrm{L}$. Turbidity can increase during and after heavy rainfall, and is considered to be an indicator of the risk of bacterial infection. The area is quite sensitive to climate change impacts, and the increasing frequency of climate extremes (droughts and heavy rainfall) can intensify the existing problems. Lower precipitation and higher evapotranspiration may result in decreasing recharge and spring discharge, whereas on the other hand, heavy rainfall entails significant karstic floods such as those of the years 1878, 1879, 1958, 2006, and 2010 .

\section{Bükk karst water-level monitoring system}

\section{Precedents}

The cold-water and thermal springs of the Bükk have been utilized for centuries as a drinking water source and for bathing. At the beginning of the twentieth century, the Tapolca springs started to be explored for the purpose of finding a drinking water supply.

The investigation of hydrochemical characteristics of the thermal springs of the Bükk area started in 1762 (Dombi 1766). The first karst hydrogeological field investigations were started by Kessler $(1955,1959)$. The hydrogeological characteristics of the Bükk area were described by Sásdi et al. (2002), Pelikán (2005), Lénárt (2005), Lénárt et al. (2014), Gondár-Sőregi et al. (2011) and Kovács et al. (2015). The first tracer tests were undertaken in 1911 (Emszt 1912), since then, 109 tracing experiments have been undertaken using 59 injection points (Sásdi et al. 2002). These experiments gave an apparent flow velocity of $15-100 \mathrm{~m} / \mathrm{h}$. The establishment of monitoring boreholes in the Bükk started in 1983 (Böcker 1969; Böcker and Vecsernyés 1983). The groundwater monitoring program, which includes the continuous registration of water levels in monitoring bores, caves and karst springs was launched in 1992. The monitoring network, which is operated by the University of Miskolc, currently includes 34 monitoring stations and a database including observations from 80 different locations (Fig. 3). Water level, temperature and electrical conductivity data have been collected at 15-60 min sampling frequency. 


\section{History of the monitoring system}

The construction of the drinking-water distribution system of the city of Miskolc started in 1913 by the implementation of Olasz Well in Miskolctapolca. Since then, the city government has satisfied the increasing water demand from karstic spring water. After World War II, heavy industry had been intensified in the area, which entailed considerable population growth. All changes in the economy, industry and the number of inhabitants resulted in increasing water extraction. In the 1970s, the water demand of the city exceeded the maximum capacity of the karst water resources, as the general water demand was over $110,000 \mathrm{~m}^{3} /$ day (in comparison, nowadays water demand is around $35,000-38,000 \mathrm{~m}^{3} /$ day). Human activity and extended water extraction from the karst aquifer made both the qualitative and quantitative protection of karst water necessary.

In the 1960s and 1970s, extensive hydrogeological research was carried out in the Bükk Mountains. Based on the research results between 1978 and 1981, five karst monitoring wells were constructed under the leadership of Tivadar Böcker (head of Karst Research Department at the Scientific Water Management Research Institute, VITUKI in Hungarian). Based on monitoring data, the protection zones of operating karst springs and thermal wells were delineated in 1987. From the beginning of the 1980s, annual rainfall started to decrease, and its effect culminated seriously in the middle of the 1990s. Since the mid-1990s, the total water demand of the large cities
(Miskolc, Mezőkövesd, and Eger) and many settlements significantly exceeded the water capacity of the karst resources in the Bükk Mountains.

Because of the long-term rainfall deficit, the waterworks in the area suffered from frequent water shortages, and also the safety of water extraction was lower than expected. The uncertainties associated with the water resources triggered the initiation of a groundwater monitoring program by the water management directorate. The University of Miskolc was engaged by the waterworks to develop a plan for a monitoring system and to undertake the operation of it in a coherent and long-term manner.

\section{Structure of the present monitoring system}

In 1992, an important development started when automatic data loggers (DATAQUA) were introduced in the monitoring wells. This ensured the availability of reliable, constant and long-term datasets (the longest dataset includes now more than 25 years of long time-series data). In the following section, some technical parameters of the system are introduced:

Measured parameters include:

- Precipitation, measured at three stations hourly, and at four stations daily

- Air temperature and soil temperature, measured at three stations hourly
Fig. 3 Location, type and water temperature of the monitoring points of Bükk Karst Water Level Monitoring System

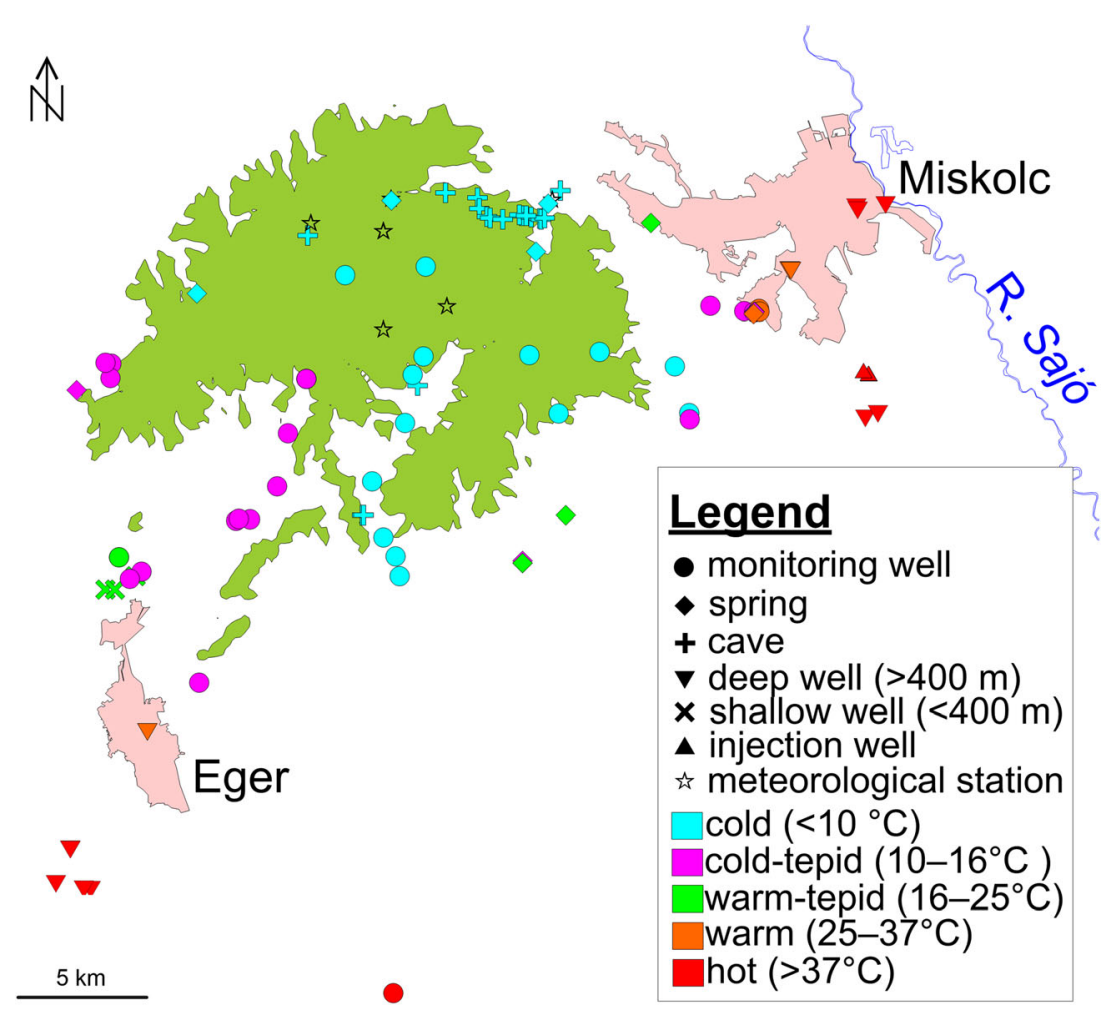


- Water level (pressure), measured at every monitoring point, with a measurement frequency of $15 \mathrm{~min}$ (currently 34 monitoring points are operating)

- Water temperature, measured at most monitoring points, with a measurement frequency of $15 \mathrm{~min}$

- Electrical conductivity, measured at some monitoring points

Monitoring points where the constant measurements take place include karst caves, cold, tepid and thermal karst springs, operating and inactive thermal karst wells, and cold and thermal observation wells. Figure 3 illustrates the location and type of monitoring points and also the characteristic water temperature at each measuring station. The monitoring points can be found all over the mountains and in their close surroundings, covering the whole area, making a large base to use datasets for various and numerous purposes. The monitoring system is expressed in numbers: number of the monitoring points is 86 (now around 30 are operating); measuring frequency is $15-60 \mathrm{~min}$, the number of daily (averaged or cumulative) data is around 330,000 , and the number of raw data samples is around $16,500,000$.

\section{Application of monitoring datasets}

The great number and long-term datasets of the monitoring system can be used for several and various purposes. The interpretation of long-term hydrogeological datasets is excellent for investigating and detecting lunisolar effects on the karst water level (Segura 2019); with the use of other datasets (like precipitation measurements) one can also make predictions of ascending and decreasing rate of the karst water level (Darabos 2012) or examine appearing subsurface floods (B. Hernádi, Mátrai Erőmű Ltd., personal communication, 2014). Constant determination (monthly and annual) of the amount of karst water resources based on registered water-level datasets is carried out every month. In further investigations, datasets were used to determine the thickness of the vertically karstified zone (Hernádi et al. 2012) or to update precise karst water level relief maps of the mountains (Miklós 2016). Furthermore, long-term datasets are suitable for investigating possible effects of climate changes in the mountains (SzegediDarabos et al. 2015). A further research area involves investigation of the connection between the cold and thermal karstwater system in the Bükk (Lénárt et al. 2014).

The water supply companies also utilize the monitoring data. Annual changes in the karst hydrogeological system are continuously analyzed and reported to the waterworks facilities, which utilize the karst water resources. Datasets of two monitoring wells are also used for tracking changes in the karst-water bodies marked in the EU Water Framework Directive and Bükk National Park; the data are informed through annual reports. The Bükk Karst Water Level
Monitoring System also served as a basis for several projects (Lénárt and Lénárt 2008; Kovács et al. 2015; Madarász et al. 2015; Gondár-Söregi and Gondár 2017). The available datasets helped to evaluate a huge karst flood event in 2006; based on the analyses, flood protection methods in the surrounding area were developed for modeling and technical solutions. Since the karst flood event in 2010, and the extremely high water-level event in 2013, the monitoring system had a crucial role in flood protection. In recent years, the Bükk karst-water monitoring system and that of an operating geothermal system are used simultaneously for investigation of the possible effects of thermal water production on the karst system.

\section{Results and discussion}

\section{Method development results based on the datasets of the monitoring system}

\section{Innovative water budget calculation method}

The long-term datasets of the Bükk Karst Water Level Monitoring System provide a good basis for establishing innovative scientific results. A karst-water budget calculation approach introduced in this study offers a new alternative tool for improved evaluation of Bükk Mountains, since all the previous calculations were based on the hydrological budget equation (Kessler 1954; Csepregi 1985; Mező 1995; Gondárné et al. 2008). The developed method uses real, accurately measured karst water-level datasets. Geographical and geological information, karst water-level datasets originating from BKWMS, and karst spring exit points from the Hungarian spring cadaster serve as the basis of the calculations.

In the work of Pelikán (2005) the Bükk Mountains were hydrogeologically divided into three main and several smaller units. According to that study, a new hydrogeological map was created. In this work, this map was further developed and all geological formations in the mountain were assorted into five groups (Fig. 2): (1) well karstified rocks; (2) poorly karstified rocks; (3) nonkarstified, fractured rocks: rhyolite tuff, dacite tuff; (4) nonkarstified, fractured rocks: others; (5) aquitard rocks (Table 1).

In the next step, the mean karst water level data and elevation of spring exit points were used to generate a groundwater relief map by using an interpolation method of natural neighbors (the size of grid was $5 \mathrm{~m} \times 5 \mathrm{~m}$ ). The results are consistent with previous researches carried out by Sásdi (2002). The water level in observation well Nv-17 was found in the range of $529.84 \pm 3 \mathrm{~m}$ with $55 \%$ absolute frequency during a 25 year-long registration period. The characteristic flow direction can also be determined by an isohypses groundwater relief 
map. This karst water-level relief map was created to model different scenarios for cases of both maximum and minimum water levels. In the last step of the method, karst water volume, based on the actual groundwater relief map and the adequate porosity, was estimated. Also, the amount of slowly refillable dynamic karst water resource was calculated for cases of varying water levels at the monitoring points. The novelty of this improved method lies in the easy usage and capability of calculating instantaneous available volume of karst water resources in the mountains. This ability serves as an excellent basis for long-term cooperation with regional waterworks companies and for development of sustainable water management in the area for the future.

\section{Results of spring- and well-hydrograph analysis}

Triassic limestones comprise an important water resource. The whole karstic system is hydraulically interconnected at the regional scale, but also includes several karstic catchments with local groundwater flow systems. Some of the subsystems are interconnected below the karstification horizon, while others are hydraulically separated by low-permeability rocks (Kovács et al. 2015).

The analysis of spring and well hydrographs undertaken by Kovács et al. (2015) revealed the basic hydrodynamic characteristics of the Bükk uplands area. The study applied the analytical solution introduced by Kovács (2003), Kovács et al. (2005) and Kovács and Perrochet (2014) for the investigation of flow dynamics and the estimation of geometric parameters of the Bükk aquifers.

Hydrograph analyses for three wells and two springs from the Szinva and Garadna catchments were undertaken. The analysis of the well hydrographs provided similar results to those of the springs. Three distinct ranges of recession coefficient could be identified. The significant difference between subsequent recession coefficients indicated a change in the scale of flow during the recession process. The baseflow component of the hydrographs indicated the drainage of an extensive aquifer zone with a size of approximately $20 \mathrm{~km}$. The intermediate and flood components indicated the drainage of low-permeability matrix blocks (Kovács et al. 2015).

Based on hydrograph analysis, it can be concluded that after the emptying of the active karstified zone of the aquifer, water level drops below the main horizontal karst conduits, and a much slower drainage of unkarstified limestone starts to dominate the recession process. At this stage, the entire karst plateau behaves as a continuous aquifer with the exception of geologically isolated subcatchments.

The hydrograph of the Garadna spring indicated that its catchment is hydraulically isolated from the main carbonate plateau of the Bükk uplands area. Block sizes (in other words conduit spacing) determined from well and spring hydrographs ranged between 300 and $700 \mathrm{~m}$. The results of this analysis confirm those of another research project carried out by Hernádi et al. (2012), in which the vertical karstification rate of the Bükk karst system was investigated. A block asymmetry, which is the ratio of average conduit spacing measured in two perpendicular directions, was determined through hydrograph analyses to be between 0.5 and 0.8 . Field observations of the topography and surface karst features including sinkholes confirmed the block size obtained through hydrograph analysis (Kovács et al. 2015).

The several orders of magnitude drop of the recession coefficient during the recession process indicated that the hydraulically active karstified horizon is related to the actual water table, and suggests that active deep phreatic conduits are missing from the system (Kovács et al. 2015).

\section{Utilization of karst water resources in the region of the Bükk Mountains}

Cold and thermal karst water resources play a prominent role in the Bükk region and there are various types of usage. One of the most important sectors is drinking water supply, but also use of geothermal heat for energy and medicinal therapy (balneology), which use thermal karst water in the area.

\section{Classification of karst water based on water temperature}

Unlike in many other countries, based on the Hungarian regulation, natural waters with temperature above $30^{\circ} \mathrm{C}$ are classified as thermal water; below this value, waters belong to the cold water category. According to many water professionals, $30^{\circ} \mathrm{C}$ is only a technical boundary which simplifies the classification of waters but, in some cases, it may set a limit to the solution of practical problems. From the practical point of view, a more detailed classification was proposed by Lénárt (2005), which reflects better the natural processes:

1. Cold (karst) water: temperature below $10{ }^{\circ} \mathrm{C}$ (as the annual mean air temperature is $10^{\circ} \mathrm{C}$ in Hungary)

2. Cold-tepid (karst) water: temperature $10-16{ }^{\circ} \mathrm{C}$ (as the mean air temperature of the hydrological summer season is $16^{\circ} \mathrm{C}$ in Hungary)

3. Warm-tepid (karst) water: temperature $16-25^{\circ} \mathrm{C}$ (international literature usually gives $25{ }^{\circ} \mathrm{C}$ as the highest interface value of cold and thermal water; Benderev and Hristov 2000; Franko 1994)

4. Warm (karst) water: temperature $25-37^{\circ} \mathrm{C}\left(37^{\circ} \mathrm{C}\right.$ is the natural temperature of the human body)

5. Hot, thermal (karst) water: temperature above $37^{\circ} \mathrm{C}$ 


\section{The utilization of karst water}

The research area investigated includes the Bükk Mountains and their surroundings, which means the thermal karst extending into the southern and western directions of the Bükk Mountains. Cold and thermal karst-water bodies were designated as documented in the River Basin Management of Hungary 1 and 2, based on the EU Water Framework Directive. Following the regulation definitions, three units were delineated (see Fig. 4): two units of cold karst-water bodies that are situated in the area of the mountains including the Bükk Western karst (k.2.1, area $534 \mathrm{~km}^{2}$ ) and Bükk Eastern karst (k.2.3, area $289 \mathrm{~km}^{2}$ ); and in the surrounding area, there is one extensive thermal karst-water body called Bükk Thermal Karst (kt.2.1), area 4,286 km² (GDWM 2010; GDWM 2015). Karst water resources of the whole region play a prominent role in water supply as they provide excellent quality drinking water and fulfill the water demands of around 400,000 inhabitants every day.

Figure 5 shows the official total annual karst-water production rates between 1993 and 2018. It should be emphasized that the actual values of production may be about $10 \%$ larger those indicated in Fig. 5, as datasets in some cases are deficient. It must also be noted, that the production rates of the operating geothermal system (see details in section 'MályiKistokaj geothermal heating plant close to the city of Miskolc') are not indicated here, because exploited water is reinjected into the karst system (total production of the system was $5,576,000 \mathrm{~m}^{3}$ in 2016 and $6,435,000 \mathrm{~m}^{3}$ in 2017).

Figure 6 shows the percentage distribution of karst water production in the region for the year 2017. It can be clearly seen that almost two-thirds $(67 \%)$ of the exploited amount of karst water is related to the Waterworks Company of Miskolc and used for satisfying water demands in the area. A further $23 \%$ of produced karst water is distributed by smaller regional waterworks companies (e.g., Waterworks of Heves County and Regional Waterworks of Northern Hungary) in the area, while the remainder $(10 \%)$ relates to thermal water production for balneological utilization.

As mentioned previously, the highest portion of exploited karst water in the Bükk region is related to the Waterworks Company of Miskolc. Figure 7 shows the production rates according to water temperature distribution in the city of Miskolc. Utilization of karst water in the Bükk region is complex, and its explanation is far beyond the scope of this report. In the following, the different types of utilization of karst water in the region are introduced. As Fig. 6 shows that the highest rate of water production is carried out for drinking water purposes (carried out by waterworks companies). The required amounts of drinking and communal water are covered from exploitation of the cold, cold-tepid, warm-tepid and warm karst water resources. One of the most important sectors of karst water consumption in the region is balneology and balneotherapy. In cases of utilization on the grounds of mineral and medicinal water quality, a so-called filling-emptying system is commonly used, otherwise warm and hot karst water resources are used. In the Cave Bath of Miskolctapolca, the pools are directly filled with warmed karst water; in the other baths, the exploited hot karst water is first cooled through a heat exchange system. Mineral and medicinal cures that involve drinking and/or inhalation of the water make up a small part of the water consumption, and these waters are mostly taken from the deep thermal karst resources (e.g. Egerszalók, Demjén thermal spa facilities). In 2010, in the city of Miskolc, a complex exploitation scheme of the geothermal system started to be put into operation. Both the exploitation and injection wells are screened in the deep hot karst aquifer and water is used for heating purposes (see section 'MályiKistokaj geothermal heating plant close to the city of Miskolc'). Finally, one should not forget the water demand for sustainability of the local ecology. In Hungary, the ecological water demand is defined individually for each water abstraction point based on the suggestions of the nature conversation authority. Mineral-water and drinking-water bottling is

Fig. 4 Cold and thermal karstwater bodies of the Bükk Mountains and Bükk Region

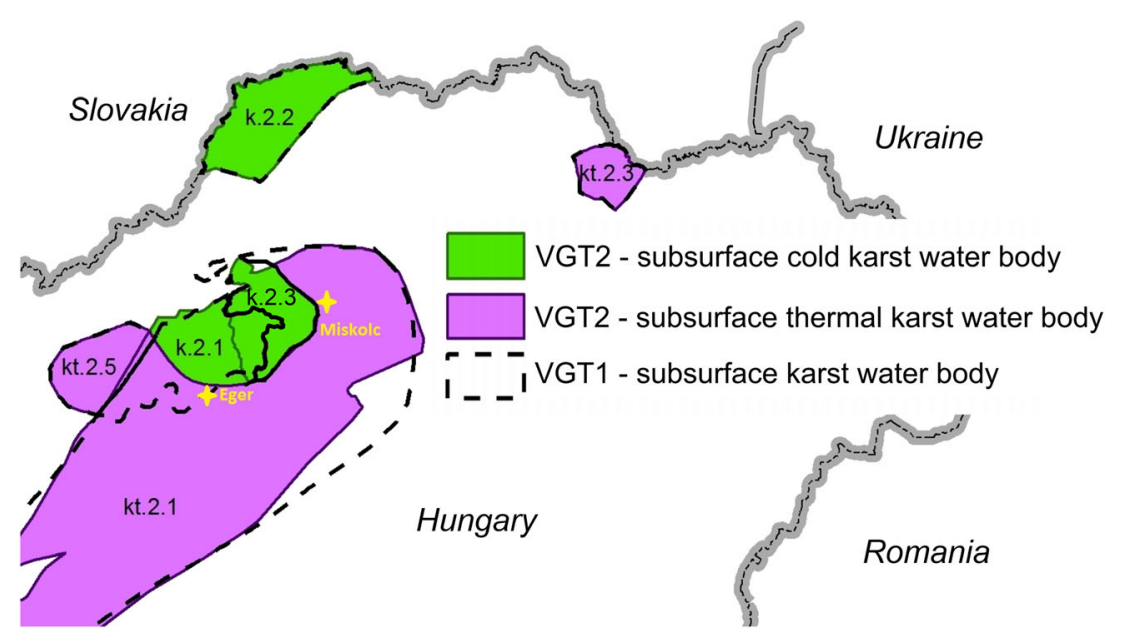


Fig. 5 Total annual karst water production in the Bükk region between 1993 and 2018 (produced ecological water demands are not included)

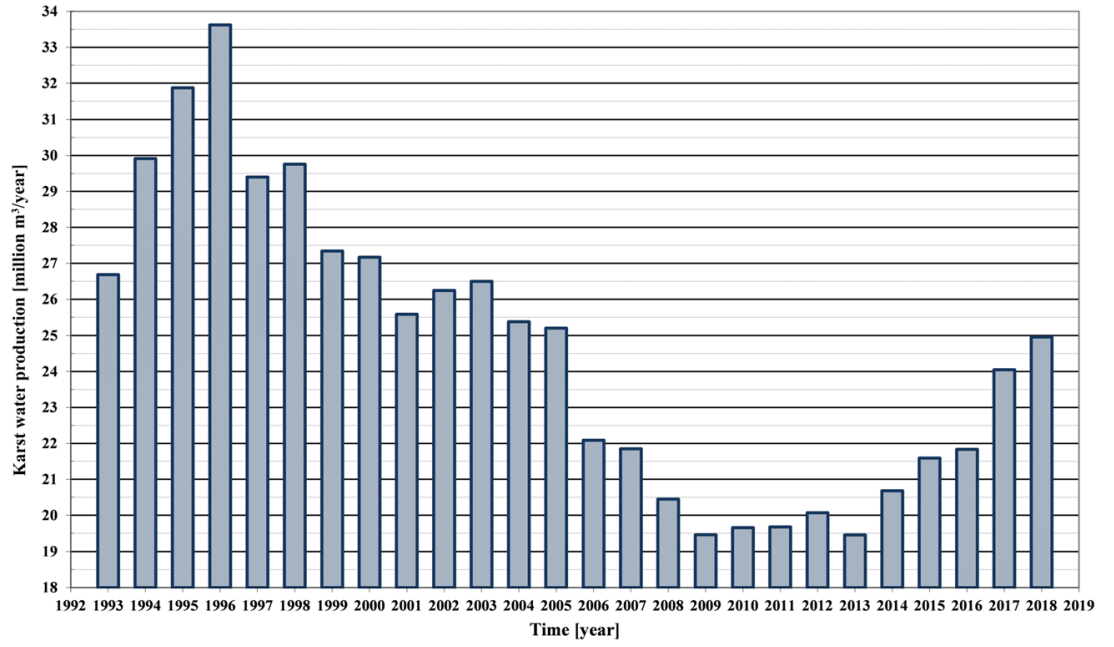

also present but its amount is negligible compared to the extracted water for all other purposes. In addition, the approximate discharge rates of effluent, unutilized springs and wells have not been taken into consideration in this report.

\section{Mályi-Kistokaj geothermal heating plant close to the city of Miskolc}

The main reason for implementation of a geothermal heating system near Miskolc in the last decade was to reduce the natural gas demand and the pollutant emission of the city. The city government saw renewable energy as a solution that ensures a cleaner and more livable environment for the residents.

Preliminary research and tests on geothermal energy usage for district heating purposes finally ended with promising results. The area established as having the best conditions was delineated in Mályi-Kistokaj, about $5 \mathrm{~km}$ from the city. Professional implementation of the project was carried out by an independent company, PannErgy PLC, with support from the city government.

The drilling process and the construction of the first exploitation well started in 2010 and the implementation concluded with even more favorable results than were predicted. The MAL-PE-01 well is 2,305 $\mathrm{m}$ deep, its discharge is around $6,600-9,000 \mathrm{~L} / \mathrm{min}$, and the temperature of the exploited water $\left(105^{\circ} \mathrm{C}\right)$ is excellent for geothermal usage. In 2012 , the MAL-PE-02 production well was also constructed with a depth of 1,514 $\mathrm{m}$, discharge of $8,000 \mathrm{~L} / \mathrm{min}$ and water temperature of $89^{\circ} \mathrm{C}$. The injection wells are also important elements of the complex energy system. The following three injection wells were implemented: KIS-PE-01 (depth $1,737 \mathrm{~m}$; injection capacity $1,600 \mathrm{~L} / \mathrm{min}$ ); KIS-PE-01B (depth $1,093 \mathrm{~m}$; injection capacity $5,600 \mathrm{~L} / \mathrm{min}$ ) and KIS-PE-02 (depth 1,058 m; injection capacity 7,000 L/min).

The main goal of the geothermal project was to link geothermal energy (renewable energy) to the district heating system of Miskolc (heat center on Avas Hill and in Tatár Street),
Fig. 6 Distribution of karst water production $\left(\mathrm{m}^{3}, \%\right)$ between waterworks companies in the Bükk and its region for the year of 2017 without geothermal exploitation rates

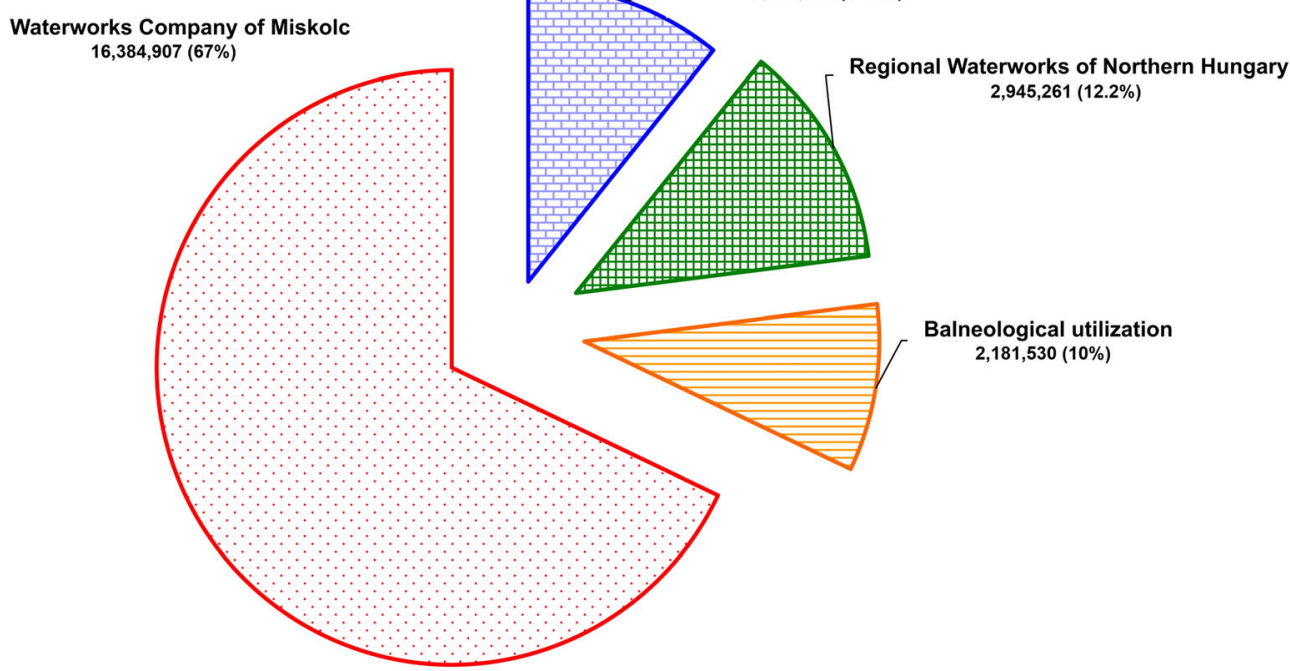




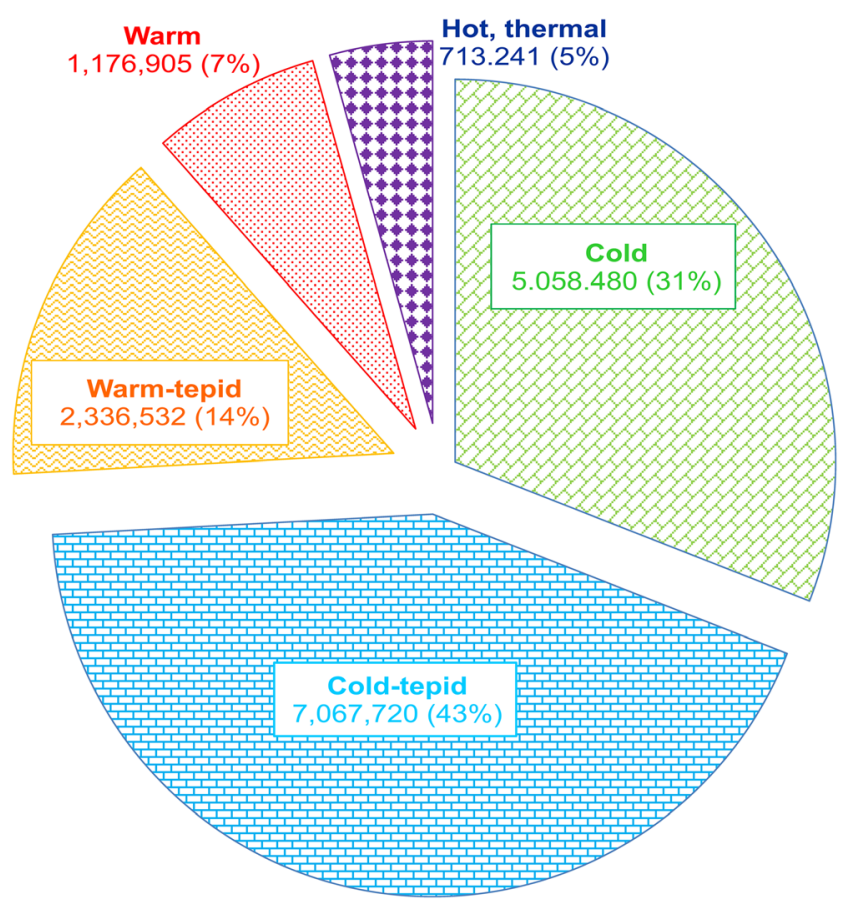

Fig. 7 Temperature distribution of exploited karst water $\left(\mathrm{m}^{3}\right)$ in the city of Miskolc for the year 2017

which supplies heat for about 10,500 flats (Fig. 8). Recovered heat output reaches the consumers through pipelines and heat exchangers, and then cooled water is reinjected. One of the most important requirements in the operation of the geothermal system is that water exploitation has to be controlled based on the current heat demand of the consumers. To ensure this control, temperature, pressure and flow meters were built into different points of the system. Based on measured data, a central remote monitoring system is able to adjust production to current needs.

In the second phase of the Miskolc Geothermal Project, a second heating plant was established in the city of Miskolc. With this step, the number of flats and apartments supplied by geothermal heat energy increased significantly (about 27,000 flats and apartments). In 2013, facilities for agriculture joined the project and now heating of a polytunnel greenhouse with a floor area of $7,000 \mathrm{~m}^{2}$ is also served by the geothermal energy. Following that, the trustee of the system set up a contract with one of the biggest industrial consumers of the city, and the heat energy demands of all the production units are now supplied by geothermal energy. Also, the whole system is completed with a heat exchanger unit and the residual heat energy exchanged from the recirculated water is used for residential and industrial consumption before reinjection. As a result, complex two-stage geothermal heat utilization is realized in the area (Fig. 8). The total heat capacity of the system has reached the $60 \mathrm{MW}_{\mathrm{t}}$. Presently, Miskolc has the largest geothermal heating plant in Hungary that is based on the thermal karst water resources of the Bükk Mountains.
As the geothermal system is exploiting thermal water from deep karst-water bodies, monitoring activity plays an important role in the operation. Continuous measuring and data recording have been carried out at almost ten monitoring points in the surrounding area of the system. Measured parameters are water level and water temperature. Some of the points monitor the cold karst water system and others monitor the thermal karst water system. As the monitoring points belong to the Bükk Karst Water Level Monitoring System, there are several long-term datasets for the past $10-15$ years. With the help of these datasets, a so-called ground state was defined for the conditions of the karst system when the geothermal project started. Based on the monitoring datasets and exploitation data (pressure, water temperature, production rates) provided by the operator, a complex scheme of interpretation and evaluation was carried out quarterly. Through the continuous monitoring, the possible effects of geothermal water exploitation can be observed. Monitoring activity has high priority in the vicinity of the system; there are several operating thermal wells serving balneological purposes and also drinking water supply wells in the karst aquifers. Constant monitoring shows that extraction rates correlate strongly with the monitoring data. These facts suggest that the whole system is hydraulically connected, but constant and consistent geothermal water exploitation did not have harmful effects on the karst system and in the exploitable amount of karstwater in the area.

As well as independent expert involvement, the company itself also carries out internal evaluation of the geothermal system annually. Results confirm that there are no significant changes in the condition of the karst system. For instance, there have not been any negative changes in the pressure condition of the exploitation wells, the injection pressure has not increased, and the exploited-water temperatures have also remained unchanged since the beginning of the operation.

\section{Conclusions}

A descriptive regional hydrogeological study is presented. Such a comprehensive description of the Bükk groundwater resources has, so far, not been published in either Hungarian or in English. Bükk Mountains represent a significant karst region with valuable groundwater resources in Hungary. This report presents the first review of the regional hydrogeological setting of the Bükk. The hydrogeological interpretation of the all available field and monitoring data revealed the complexity of the overall karst water system. The monitoring data and the flow-system investigations also confirmed the close relationship between the cold and thermal karst water systems in the Bükk Mountains. The available groundwater resources are limited according to the annual natural recharge. Besides the regional drinking water supply, there is an increasing demand 
Fig. 8 Depiction of the MályiKistokaj complex two-stage geothermal heat utilization system containing two exploitation wells, three injection wells, primary heat usage in Miskolc (Avas Hill and Tatár Street) and secondary heat usage (industrial consumer and polytunnel greenhouses heating)

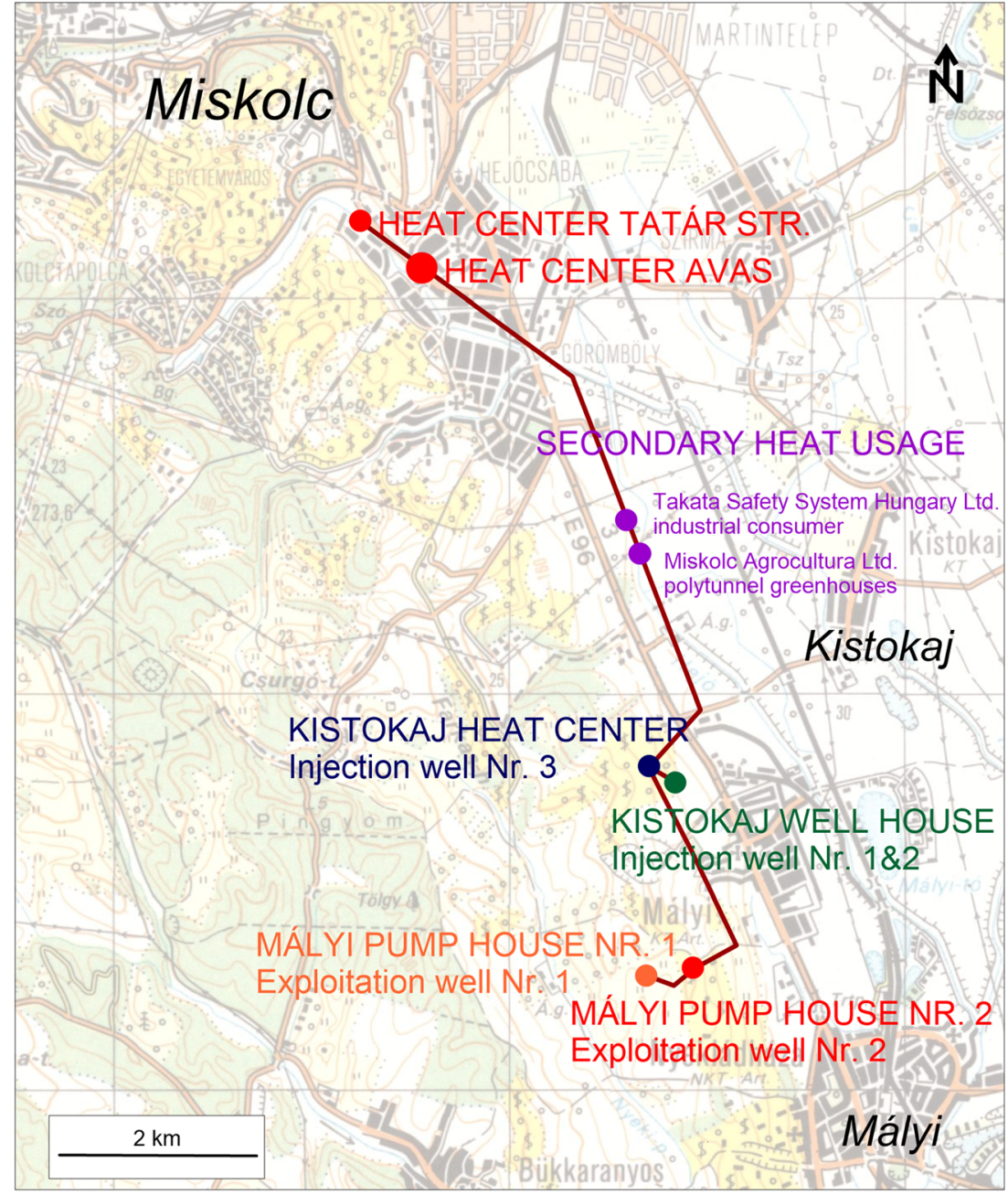

on the thermal water production around the Bükk Mountains. The different measures taken by the regional groundwater management to ensure resource sustainability are necessary to maintain sustainable utilization. The effects of extreme weather conditions on the water levels can be clearly observed already. From series data, it is seen that the lowest karst water level is continuing to fall, and the highest water level is continuing to rise (Darabos et al. 2016) which, in time, will cause problems in water management. As a result, the drinking water supply is facing more frequent challenges especially after long dry periods. It can be predicted that other types of utilization may also be affected in the future. There is a new project, in preparation phase, in which a new real-time, smart flood-warning system will be developed in the city of Miskolc. The system will also rely on the measurements of the Bükk Karst Water Level Monitoring System, providing quick and effective precautions in case of emergency. The largest geothermal heating plant in Central Europe, operating in Miskolc, with $60 \mathrm{MW}_{\mathrm{t}}$ capacity, is exemplary for demonstrating the sustainable utilization of deep thermal karst water resources. This overview can be considered as a comparative study for hydrogeology professionals who can fruitfully make use of the approaches developed when studying other large karst systems with complex utilization.

Funding information Open access funding provided by University of Miskolc (ME). The research was carried out in the framework of the GINOP-2.3.2-15-2016-00010 'Development of enhanced engineering methods with the aim at utilization of subterranean energy resources' project of the Research Institute of Applied Earth Sciences of the University of Miskolc in the framework of the Széchenyi 2020 Plan, funded by the European Union, co-financed by the European Structural and Investment Funds.

Open Access This article is licensed under a Creative Commons Attribution 4.0 International License, which permits use, sharing, adaptation, distribution and reproduction in any medium or format, as long as you give appropriate credit to the original author(s) and the source, provide a link to the Creative Commons licence, and indicate if changes were made. The images or other third party material in this article are included in the article's Creative Commons licence, unless indicated otherwise in a credit line to the material. If material is not included in the article's Creative Commons licence and your intended use is not permitted by statutory regulation or exceeds the permitted use, you will need to obtain permission directly from the copyright holder. To view a copy of this licence, visit http://creativecommons.org/licenses/by/4.0/. 


\section{References}

Benderev A, Hristov V (2000) The subthermal karstic waters of Bulgaria, their current state and potential for the sustainable development. Sustainable Mineral Resources Management in Karst Areas. NATO ARW, Portoroz, Slovenia, pp 49-50

Böcker T (1969) Az első karsztvíz megfigyelőkút a Bükk hegységben [The first karstwater level monitoring well in the Bükk Mountains]. Hidrológiai Tájékoztató 1969(June):108-109

Böcker T, Vecsernyés Gy (1983) Miskolc város vízellátására foglalt karsztforrások védőidomának víz- és környezetvédelmi atlasza [Water and environmental protection atlas of the protective areas of karst drinking water springs in Miskolc city]. ALUTERV, Budapest

Csepregi A (1985) A karsztos beszivárgás számítási módszereinek összehasonlítása a vízszintváltozások elemzése alapján [Comparison of infiltration calculation methods in karst areas based on analysis of karst water level changes]. Hidrológiai Közlöny 3: $130-133$

Darabos E (2012) Analysis of precipitation groups and related water level peak times in the Bükk Mountains. Geosci Eng 1(1):103-111

Darabos E (2017) Vízkészlet számítás és idősorok elemzése karsztosodottsági jellemzők meghatározása céljából a Bükki Karsztvízszint Észlelő Rendszer adatai alapján [Water budget calculation and time series analysis of data from the Bükk Karst Water Level Monitoring System for determining karstic features]. $\mathrm{PhD}$ Thesis, BKÉR, Miskolc, Hungary

Darabos E, Miklós R, Kovács P, Szücs P, Lénárt L (2016) A bükki karsztvíz észlelő rendszer adatainak vizsgálata a hegységben jelentkező klímaváltozás jellegének és következményeinek meghatározásához [Investigation of datasets of the Bükk Karst Water Level Monitoring System to determine the characteristics and consequences of climate change in the mountains]. XII: Kárpát-medencei Környezettudományi Konferencia, Beregszász, Ukraine, June 2016, pp 72-81

Deák J (1989) Dating the thermal waters in the Eger area. 10th Int. Congress of Speleology, Budapest, 1989

Dombi S (1766) Relatio de mineralibus inclyti Comitatus Borsodiensis aquis facta ad excelsum consilium regium locumtenentiale [Report about the beauty of mineral waters in Borsod County]. Bader Imre Felix kiadás, $23 \mathrm{pp}$

Emszt K (1912) Jelentés a m. k. Földtani Intézet chemiai laboratóriumának 1911 . évi múködéséről [Report about the operation of Hungarian Geology Survey chemical laboratory in 1911]. In: A magyar kir. Földtani Intézet évi jelentése 1911-ről, Budapest, pp 203-222

Filipović I, Jovanović D, Sudar M, Pelikán P, Kovács S, Gy L, Hips K (2003) Comparison of the Variscan, early Alpine evolution of the Jadar block (NW Serbia) and "Bükkium" (NE Hungary) terranes: some geological implications. Slovak Geol Mag 9(1):23-40

Franko (1994) Hydrogeotermics of Czechoslovakia. Int Assoc Hydrogeol $15: 21-42$

GDWM (General Directorate of Water Management) (2010) Vízgyüjtőgazdálkodási Terv [River basin management of Hungary, vol 1]. GDWM, Budapest

GDWM (General Directorate of Water Management) (2015) Vízgyüjtógazdálkodási Terv [River basin management of Hungary, vol 2]. GDWM, Budapest

Gondárné K, Székvölgyi K, Gondár K, Gyulai T, Könczöl N, Kun É (2008) Egy új módszer az utánpótlódó felszín alatti vízkészlet számítására hegyvidéki víztestek területén [New method for calculating the amount of dynamic water resources in mountainous area]. Magyar Hidrológiai Társaság, XXVI. Országos vándorgyülés, Budapest, pp 667-681
Gondár-Sőregi K, Gondár K (2017) A bükki karsztvíz észlelő rendszer bővítése és a mért eredmények felhasználása a Bükk környékének vízgazdálkodásában [Expansion of Karstwater monitoring system in the Bükk Mountains and application of the results in groundwater management of the Bükk region]. Müszaki Földtudományi Közlemények 86(3):92-98

Gondár-Sőregi K, Gondár K, Székvölgyi K, Kun É, Simonffy Z, Ács T, Tahy Á (2011) Climate change and impacts on water supply. Bükk Mountains Test Area. CC-WaterS project, European Regional Development Fund (ERDF), Brussels, $51 \mathrm{pp}$

Hernádi B, Lénárt L, Horányi-Csiszár G, Tóth K (2012) A bükki nyílt karszt vertikális karsztosodottsága [Vertical karstification of Bükk open karst system]. Karsztfejlődés XVII, Szombathely, Hungary, 2011, pp 63-78

Izápi G, Maucha L (1992) A Bükk-hegység vízháztartási vizsgálata [Water balance investigation of the Bükk Mountains]. A Bükk karsztja, vizei, barlangjai Konferencia, Miskolc, Hungary, 1992

Izápi G, Sárváry I (1993) Tájékoztató a magyarországi karsztos termálvíz előfordulások állapotáról [Informative about the condition of thermalkarst reservoirs in Hungary]. Vízgazdálkodási Tudományos Kutatóintézet, Budapest, 11 pp

Kessler H (1954) A karsztból tartósan kitermelhető vízmennyiség és a beszivárgási százalék megállapítása [Determination of the volume of sustainably extractable karst water and determination of infiltration rate]. Hidrológiai Közlöny 34(5-6):213-222

Kessler H (1955) Der Versickerungsbeiwert in Karstgebieten [Infiltration percentage in karst areas]. Wasserwirtschoft-Wassertechnik 5(12): 392-395

Kessler H (1959) Az országos forrásnyilvántartás [Spring register of Hungary]. Vízgazdálkodási Tudományos Kutatóintézet, Budapest

Kovács A (2003) Geometry and hydraulic parameters of karst aquifers: a hydrodynamic modeling approach. PhD Thesis, University of Neuchâtel, Switzerland

Kovács A, Perrochet P (2014) Well hydrograph analysis for the estimation of hydraulic and geometric parameters of karst aquifers. In: Mudry J, LaMoreaux JW (eds) H2Karst research in limestone hydrogeology. Environmental Earth Sciences Book Series, Springer Science and Business Media, Heidelberg, Germany, pp 97-114

Kovács A, Perrochet P, Király L, Jeannin P-Y (2005) A quantitative method for the characterization of karst aquifers based on spring hydrograph analysis. J Hydrol 303:152-164. https://doi.org/10. 1016/j.jhydrol.2004.08.023

Kovács A, Perrochet P, Darabos E, Lénárt L, Szücs P (2015) Well hydrograph analysis for the characterisation of flow dynamics and conduit network geometry in a karstic aquifer, Bükk Mountains, Hungary. J Hydrol 530:484-499. https://doi.org/10.1016/j.jhydrol. 2015.09.058

Lénárt L (2005) Some aspects of the "3E's" (Economics-EnvironmentEthics) model for sustainable water usage in the transboundary Slovakian and Aggtelek karst region based on some examples from the Bükk Mountains. PhD Thesis, Search ResultsWeb resultsTechnical University of Košice, Košice, Slovenia

Lénárt L, Lénárt E-I (2008) A GVOP 3.1.1.-2004-05-0530/3.0 VIMORE projekt keretében végzett bükki barlangi karszthidrológiai mérések összefoglaló értékelése [Assessment of cave karsthydrogeological measurements carried out in the frame of A GVOP 3.1.1.-200405-0530/3.0 VIMORE project]. Karsztfejlődés XIII, Szombathely, Hungary

Lénárt L, Hernádi B, Szegedi-Darabos E, Zs D, Czesznak L, Tóth M (2014) The importance of Bükk karst water monitoring system (BKWMS) in researching the relations of cold and warm karst waters in the area. Geosci Eng 3(5):107-117

Madarász T, Szücs P, Kovács B, Lénárt L, Fejes Z, Kolencsik-Tóth A, Székely I, Kompár L, Gombkötő I (2015) Recent trends and activities in hydrogeologic research at the University of Miskolc, 
Hungary. Central Eur Geol 58(1-2):171-185. https://doi.org/10. $1556 / 24.58 .2015 .1-2.11$

Mező G (1995) Távlati vízbázisok biztonságba helyezésének programja: a bükki karsztrendszer földtani, vízföldtani és szimulációs modellje [Program of security of water resources: geological, hydrogeological and simulation model of the Bükk karst system]. Research report, BKMI, Budapest

Miklós R (2016) Bükki források összehasonlító vízkémiai vizsgálata karszthidrogeológiai kutatás keretében [Comparison of springs in the Bükk Mountains based on water chemistry measurements in the frame of karst hydrogeological research]. MSc Thesis, University of Miskolc, Hungary

Pelikán P (ed) (2005) Geology of the Bükk Mountains, Hungary. Mining and Geological Survey of Hungary, Budapest

Sásdi L (2002) Vízrajzi, vízföldani viszonyok [Hydrographical, hydrogeological conditions]. In: Baráz Cs (ed) (2002) A Bükki Nemzeti Park [The Bükk National Park]. Bükk National Park Directorate, Eger, Hungary
Sásdi L, Gy L, Pelikán P (2002) A Bükk karsztvíztározó összleteinek térbeli lehatárolása [Spatial delineation of karstwater aquifers in the Bükk Mountains]. In: Karsztvízkutatás Magyarországon II. Bükk-térség Fenntartható Vízkészlet-gazdálkodás Közalapítvány, Miskolc, Hungary, pp 7-13

Segura M (2019) Investigation of tidal effects on the karst water level in the Bükk Mountains, Hungary. MSc Thesis, University of Miskolc, Hungary

Szegedi-Darabos E, Lénárt L, Tóth M, Miklós R, Hernádi B, Czesznak L (2015) A Bükk karsztvizei [Karst waters of the Bükk]. Mérnökújság 22(7-8):7-19

Szücs P, Horne RN (2009) Applicability of the ACE algorithm for multiple regression in hydrogeology. Comput Geosci 13:123-134. https://doi.org/10.1007/s10596-008-9112-z

Szűcs P, Civan F, Virag M (2006) Applicability of the most frequent value method in groundwater modeling. Hydrogeol J 14(1):31-43. https:// doi.org/10.1007/s10040-004-0426-1 